\title{
ARMENIAN CITY OF GYUMRI AS A PHENOMENON OF LIVING VERNACULAR URBAN ENVIRONMENT
}

\author{
A. Ivanov $1, *$ \\ ${ }^{1}$ International Academy of Architecture, Moscow Branch - andreyivanovarch@mail.ru
}

Commission II - WG II/8

KEY WORDS: Living Vernacular City, Vernacular Ensemble, Regular Vernacular, Architectural Improvisation, Neo-vernacular House, Mason

\begin{abstract}
:
Architectural and environmental peculiarities of Gyumri (former Alexandropol, Leninakan) located in the Republic of Armenia lie in the vernacular: a significant layer of historic "architecture without architects" (Bernard Rudofsky) built by local skilled stonemasons from the local material called black tuff. In the late 19th and early 20th centuries, Gyumri was the largest city in Eastern Armenia (Armenia within the borders of the Russian Empire) and its economic and cultural centre. The historic part of the city is a regular grid filled with one- or two-storey stone vernacular buildings (under the unwritten principle "freedom within the grid"). Until now, despite the devastating earthquakes of 1926 and 1988, it remains practically authentic and serves as a living multifunctional city core. This article introduces new theoretical concepts of the living vernacular city and the vernacular ensemble, developed by the author, and examines the peculiarities of vernacular architecture emergence at different stages of urban formation. The author also investigates the phenomenon of the almost incessant vernacular development of the city, which took place not only during the city's heyday, but also in the Soviet times when private architectural activity was officially forbidden, and today when we see the revival of spontaneous vernacular construction - in excessively decorated forms, but with the same traditional methods and the masters' love for their works. Methods of detailed visual analysis of the built environment and in-depth interviewing of vernacular actors were used in the preparation of the study.
\end{abstract}

\section{GYUMRI: UNIQUENESS}

That far land we dream about,

Where every man is his own architect.

(Robert Browning)

\subsection{General information about the city}

The city of Gyumri was previously called Kumayri (according to ancient Greek historians, it existed in the 8th century BC), Gumry (18th-early 19th century), Alexandropol (the fortress was founded in 1835; the city was established in 1840), and Leninakan (1924-1991). By the end of the 19th century, it was the largest city of Russianruled Eastern Armenia, an important economic and cultural centre of the South Caucasus, a place of deployment of the Russian military garrison near the border with the Ottoman Empire. The city's historic part, low-rise neighborhoods built with hardly any architects involved, remained authentic during the Soviet period as a multifunctional city centre. However, in 1988 the city was ruined by an earthquake, which added up to a number of other traumatic events: Soviet production facilities shut down; independent Armenia faced an economic crisis; most active and educated citizens moved away.

But the city lives and develops mainly on its own, relying on the inborn urban culture of the townspeople, unique local traditions, and perseverance of the remaining inhabitants.

\subsection{Main stages of development}

Alexandropol/Leninakan/Gyumri inherited and developed features of the local architecture typical of the Western Armenian cities which had become part of the Ottoman Empire. Those cities (Van, Muş, Kars, etc.) were where the first Alexandropol masons came from when in 1829 Eastern Armenia was annexed to Russia. Their descendants and followers have been creating vernacular architecture up until today, using local housing traditions and improvising within the unwritten, yet generally accepted rules.

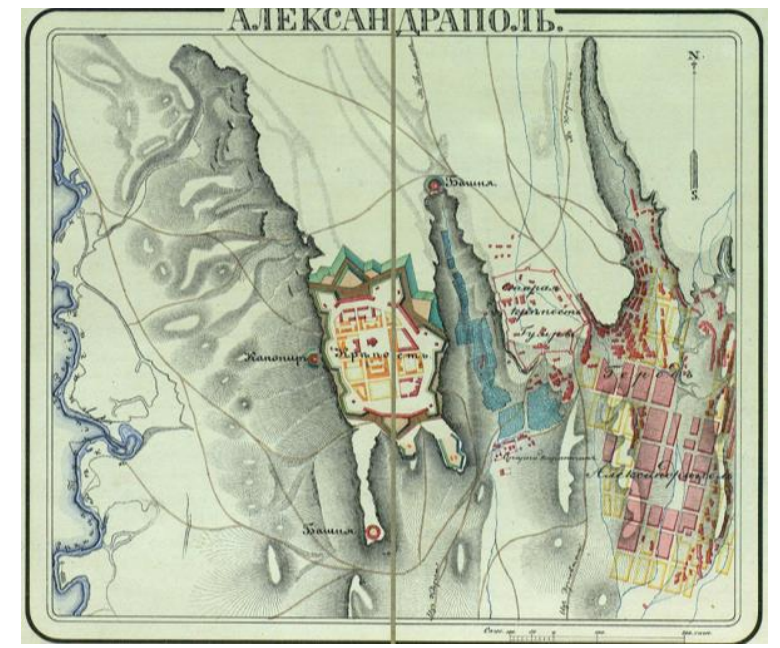

Figure 1. Plan of the fortress and town of Alexandropol, 1830s (Atlas Krepostey Rossiyskoy Imperii, s. a.).

\footnotetext{
* Corresponding author
} 


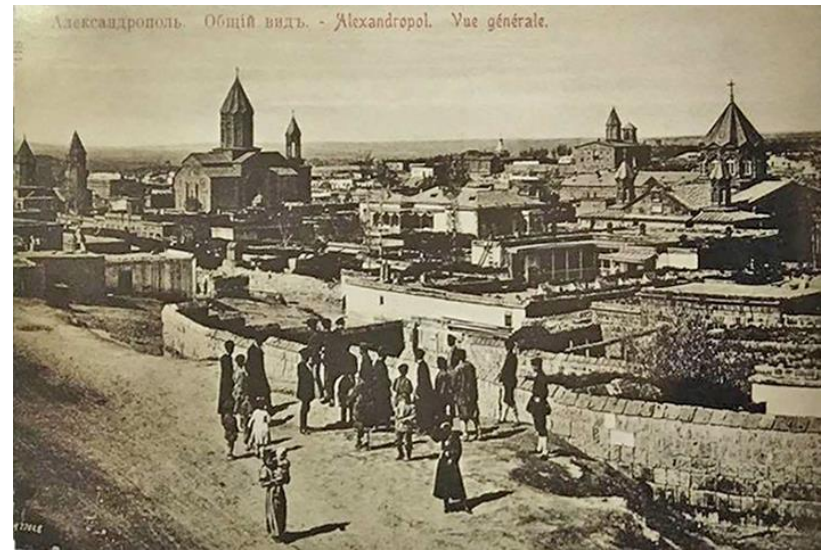

Figure 2. General view of Alexandropol. Postcard from 1900s.

We can distinguish the following four stages of the city's vernacular development: traditional (1830s to 1870 s, when a regular grid plan for the city was developed and the first stone houses were built); multicultural (1880s to 1910 s, when the city was flourishing after the Russian annexation of the nearby Kars region and construction of the railroad to Kars, which allowed Alexandropol to take in the newest architectural trends without having to betray its own identity); compensatory (1920s to 50s, when the vernacular construction of private houses funded by the citizens continued despite the official Soviet government's policy); neo-vernacular (1990s to now, when the interest in building traditional black tuff private houses is being revived after the era of modernist architecture and mass production of multifamily housing). But even in $1960 \mathrm{~s}-80 \mathrm{~s}$, there were independent housebuilders in the city, and the vernacular tradition essentially went on.

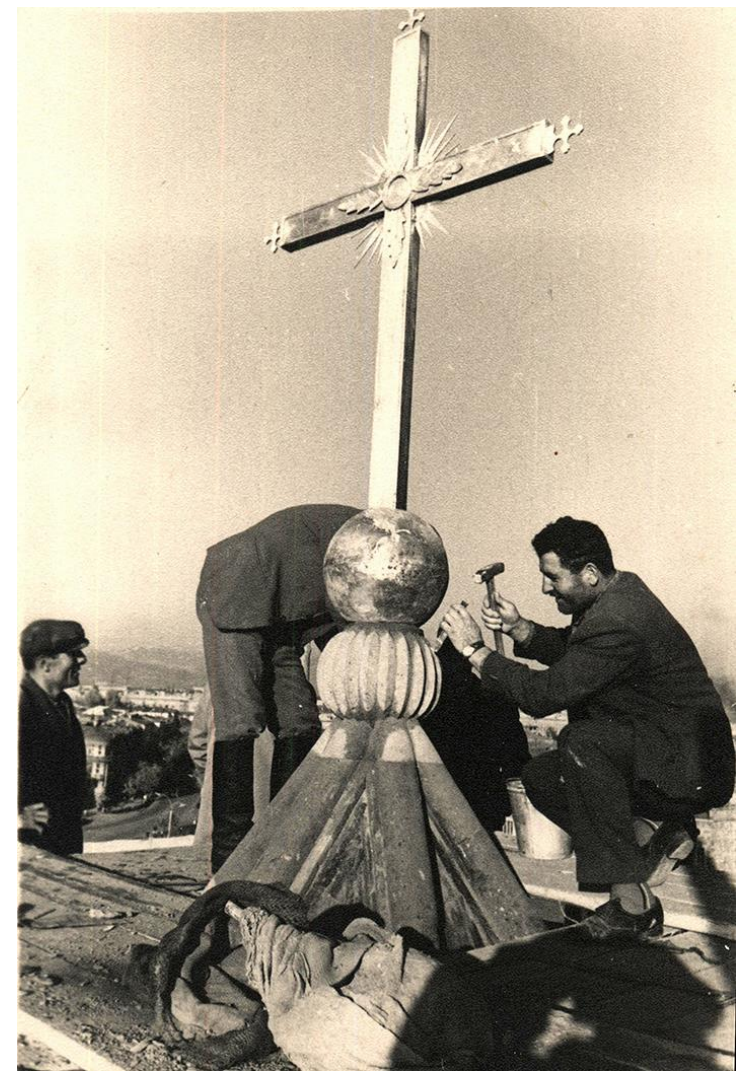

Figure 3. Rebuilding of the St. Savior Church bell tower, 1965. (Retrieved January 23, 2020, from http://cfa.am/en/construction-masters).

\subsection{Vernacular construction method}

In architecture, the term vernacular is used to describe housing constructed with no involvement of professional architects and characterised by certain aesthetic and environmental merits, which Bernard Rudofsky described as architecture without architects (Rudofsky, 1964). Such housing drew more and more attention throughout the 20th century, which then took shape as the Charter on the Built Vernacular Heritage adopted in 1999 by the ICOMOS 12th General Assembly in Mexico. The Charter reads:

The built vernacular heritage (...) appears informal, but nevertheless orderly. It is utilitarian and at the same time possesses interest and beauty. It is a focus of contemporary life and at the same time a record of the history of society. Although it is the work of man it is also the creation of time. It would be unworthy of the heritage of man if care were not taken to conserve these traditional harmonies which constitute the core of man's own existence. (Charter on the Built Vernacular Heritage, 1999).

A well-known researcher of the vernacular, Allen Noble, suggested distinguishing between the folk and the vernacular architecture. He believes that folk building or folk architecture is built by "persons not professionally trained in building arts", where vernacular architecture is still of the common people but may be built by trained professionals such as through an apprenticeship, but still using local, traditional designs and materials (Noble, 2007).

Trained professionals like those were the main actors of Alexandropol's development. For planning and building, they used and actualised architectural "prototypes" (houses already built by them or by other masters) and "samples" (designs and blueprints of various buildings, published in catalogues and albums).

In his article on the architecture of Leninakan (1954), a famous Armenian architect Rafael Israelyan, known for his subtle appreciation of Armenia's historic architecture, highlighted the local masters' practice of using historical prototypes:

One can especially notice the resemblance of the architecture of city of Ani in the creations of the professional craftsmen of Alexandropol/Leninakan. The matter is that the masters (...) of 19th century would not blindly follow or yield the demands and traits of the past architecture but they have continued according to the modern demands, developed it so that it looked relevant to modern architecture and yet followed the old traditions. (Israelyan, 1982).

As any sustainable system, the developing city relied heavily on the dwellers' response: prototype - new house - reception by peer masters, client and his neighbours - drawing on feedback and perfecting the skills - next building, usually more advanced.

Churches were built the same way. The St. Savior Church (Amenaprkich) can serve as a good example. The biggest church in the city (and at the time the tallest Armenian church worldwide), funded by residents' donations, was built in 18591866 as a copy of the cathedral in Ani, one of the ancient Armenian capitals the ruins of which lie not far from Alexandropol. The construction was led by the local master Tadevos Andikyan. Every Sunday for fourteen years, master Tadevos took a ride to Ani to take measurements of the cathedral, carefully considering every little detail in Alexandropol's grand project. 

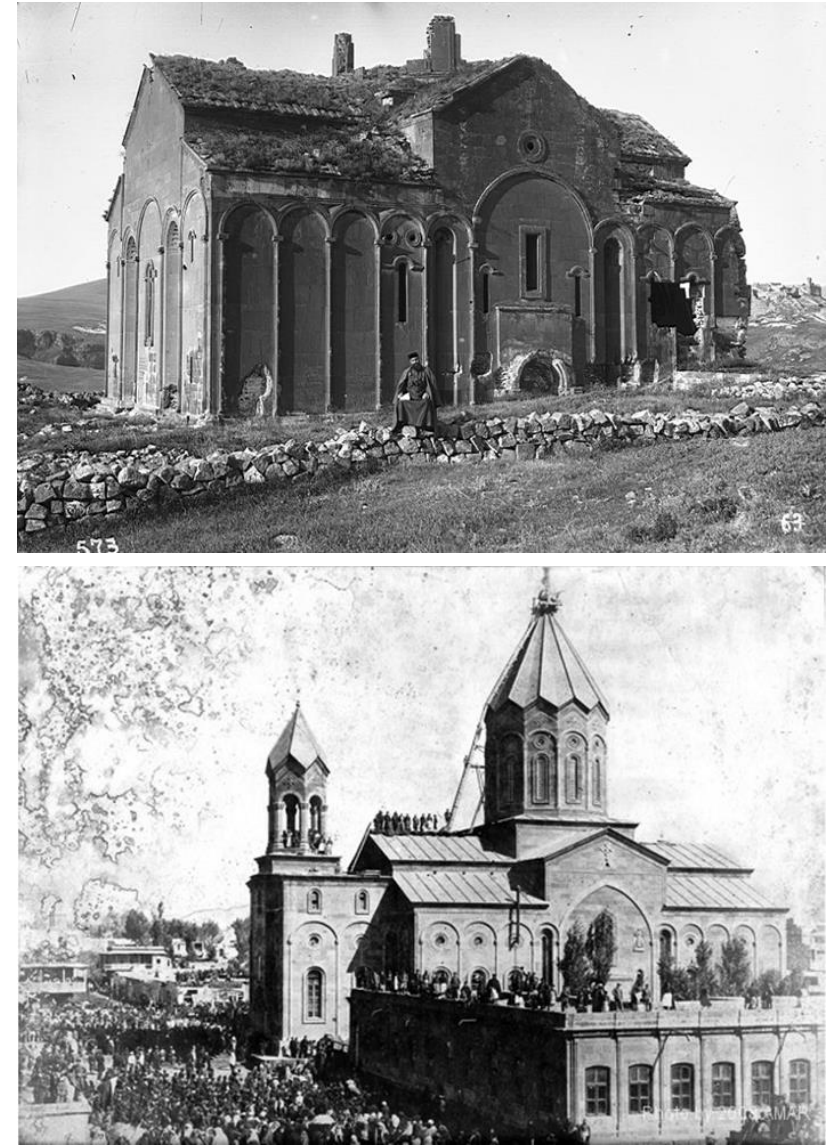

Figure 4. Above, the Cathedral of Ani (built in 989-1001); below, the St. Savior Church in Alexandropol.

Photos from the early 20th century.

Notably, the builder of Amenaprkich, whom the citizens called the master of masters, was able to appreciate Ani's thousandyear-old architectural marvel long before professional architectural historians. But then, he approached the Amenaprkich construction as he would any regular residential building, drawing from the model, yet improvising on every stage. The new church is bigger, its proportions and details are amended: he added lancet arches, a bell tower, a dome. The image of the Cathedral of Ani served as some sort of frame for the master's work.

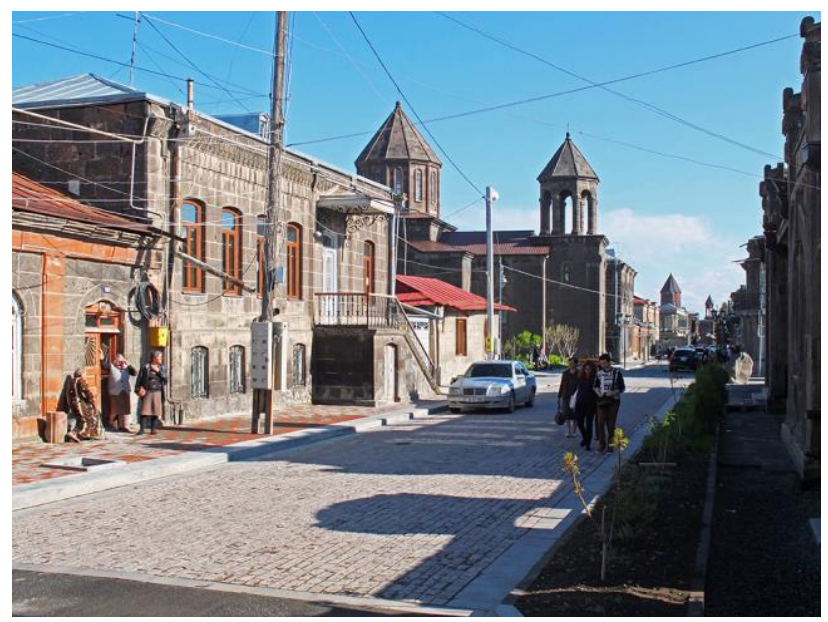

Figure 5. Vernacular ensemble of Abovyan Street. Photo by the author, 2019.

\subsection{Living vernacular city: freedom within the grid}

One of the first Russian adherents of the concept of architectural and environmental vernacular was urbanist Alexander Vysokovsky. In his 2013 lecture "Vernacular city", Alexander spoke of "an invisible but very powerful structure for understanding and identifying the place citizens live in" as "a mental structure generated by people themselves in their everyday life", and called it "a vernacular city or vernacular structure, by analogy with vernacular district and other vernacular constructs, that are not the result of conscious technical or scientific activities, but arise in the process of living, dwelling and taking root, interacting with surrounding physical objects and social environment." (Vysokovskiy, 2013).

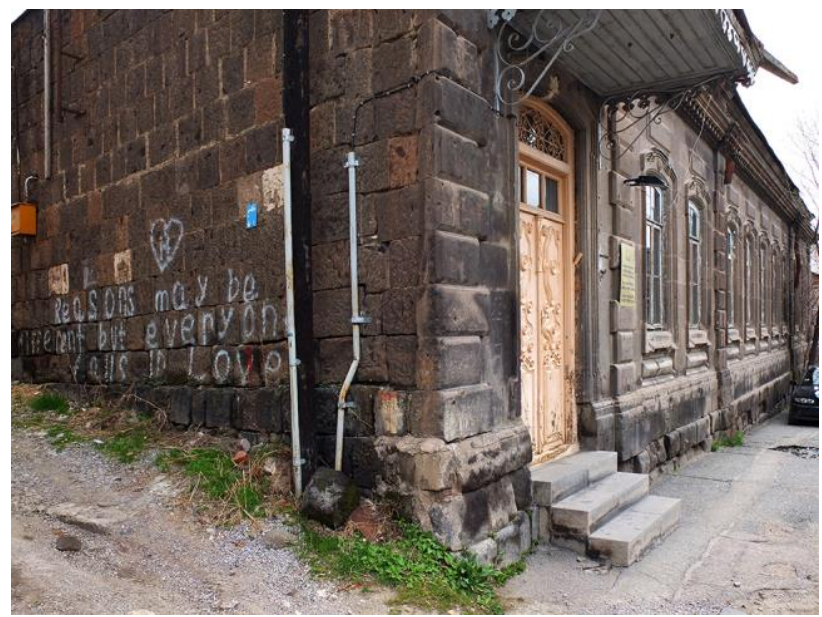

Figure 6. Facades of a typical vernacular house on Pushkin Street. Photo by the author, 2017.

Gyumri's uniquely preserved historical vernacular throws some light on the formation and existence of its special type, the "regular" vernacular, created by skilled local masons, actors of the median architectural culture. It was them who created the city of Alexandropol in the "freedom within the grid" paradigm, with only a formal participation of military and civil engineers (while any possible involvement of professional architects has not yet been confirmed). But even when certified architects came to Leninakan in the mid 1920's, "ordinary" private residential buildings were most often built in the same vernacular way. In today's Gyumri, traditions of the Alexandropol vernacular are still alive. Wealthy citizens who build houses in the historic centre have not lost interest in architecture and tend to use the local stone construction techniques, even though it entails a rather sizeable "beauty expense". The following two points are essential to understanding this city's special character.

A) Alexandropol was a city in that ancient or early medieval sense which implies that it chiefly develops through self-activity of its citizens, artisans and masters, masters of their own lives, skillfully and beautifully building their "horizontal" world. But this city had to be built within the pre-defined boundaries:

- Planning (regular grid pattern);

- Legal (decrees on building within the grid and on obtaining approval for "framework" construction projects, city authorities' orders on "road rectification", etc.);

- Aesthetic (use of architectural prototypes and patterns, both "higher", as the Cathedral of Ani, and "median", as the various albums and catalogues of model projects, popular with the townspeople). 


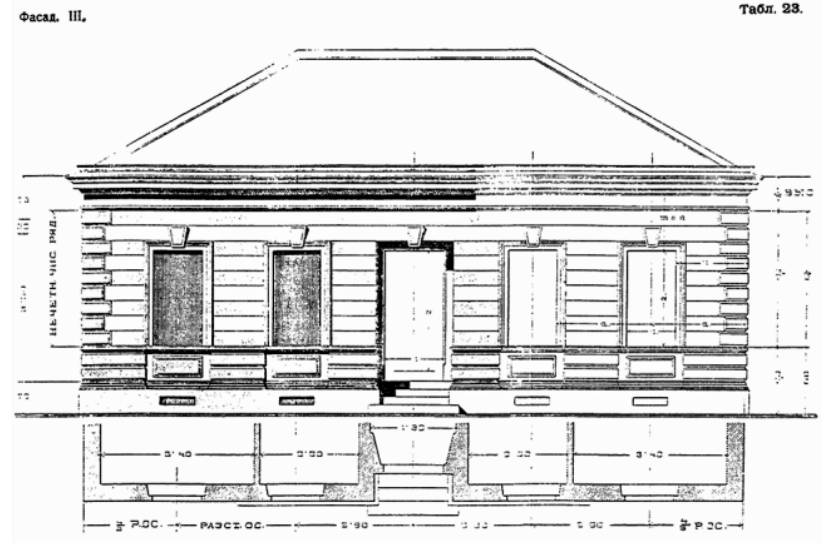

ОДНОэТАЖНЫЕ ЖИЛЬЕЕ ДОМА ІЪ ПРОСТОЙ ОТДПЛКОЙ

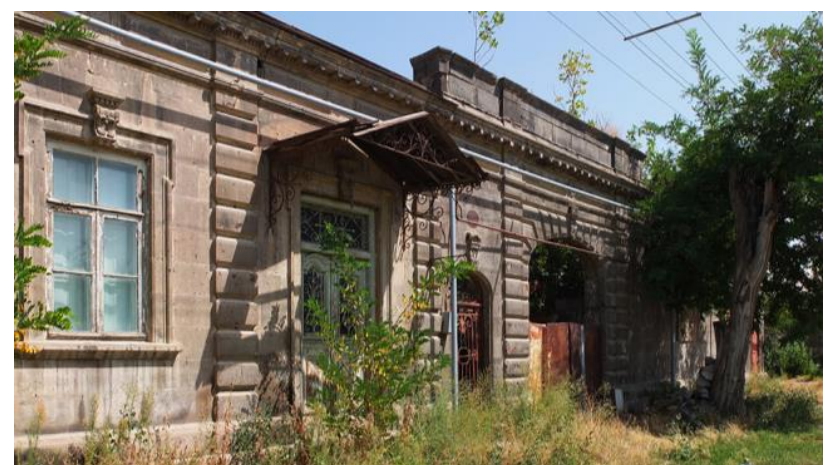

Figure 7. Table from an album (Brausevetter, 1904); residential building on Tumanyan Street (early 20th century) mostly likely built as per a similar catalogue and completed with a grand arched gate. Photo by the author, 2016.

B) It was a free city created mostly by common people with hardly any involvement of the bureaucracy.

The city was run by the tsar's officials, but they never managed to get deep into its life, never got a chance to paint it their trade colour, gray. While there were policemen in the streets and troops in the outer-city garrison and in the fortress, it was just a ring embracing the city life on the surface, from the outside. Inside this ring Gyumri had its own colours and protected them with all its might. (Armen, 1984).

On the city scale, the administrative functions were concentrated in the Alexandropol fortress (the city was governed from the outside rather by the military than by the civil authorities. As a border city, it was granted a number of special financial and economic benefits); and on the regional scale, in Yerevan, designated as a provincial centre, but at that time smaller in population, more "Eastern" and less developed than Alexandropol. The core of AlexandropolGyumri's architectural and environmental phenomenon is this strong median environment-forming layer of historical vernacular architecture existing across the "higher" and the "lower" architectural cultures.

Yet the Gyumri phenomenon goes beyond architecture as such. What we have here is a living vernacular city, and not exactly in the sense intended by A. Vysokovskiy. For him, a vernacular city is a "mental structure" that develops while people are settling down in the environment they were given, comprehending it. But in this case, in addition to that concept and prior to it, we have a city that has been initially developed in the vernacular way. For Gyumri, this term is no longer a metaphor or a theoretical concept, but an exact description of the actual situation.
Today, in most of the cities considered historic there are only "frozen" traces of the vernacular, certain relict buildings that are probably even included in heritage preservation lists. Gyumri, on the other hand, remains a living vernacular city where spontaneous, grassroots vernacular practices still exist. The social, active, narrative content of the environment, largely following the historical tradition, is no less important here than its actual architectural components. Over the years, a simple planning grid has been superimposed with dense and complex networks of multiform human interactions, economic and cultural transactions, heterogeneous artistic images, urban legends, anecdotes, and life stories. And unlike the initial grid, those were not planned by anyone, but emerged naturally, self-organised and stochastic.

This superimposition of spontaneous and planned is still happening today. And one of the results is the unintentional beauty of the urban environment.

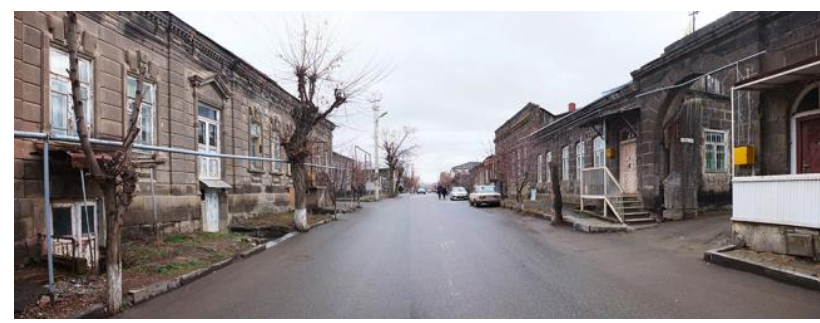

Figure 8. Vernacular ensemble of Spandaryan Street. Photo by the author, 2018

\section{VERNACULAR LEXICON OF GYUMRI}

anyone lived in a pretty how town (with up so floating many bells down) spring summer autumn winter he sang his didn't he danced his did. Edward Estlin Cummings

\subsection{Vernacular ensemble}

An important aspect of Gyumri's uniqueness is the aesthetic qualities of the city's material substance. We can describe its historic centre not simply as a vernacular environment of the median level, but as an environment of very high architectural and artistic quality. To address this urbanistic phenomenon more accurately, I suggest the term vernacular ensemble (VE). Isn't that some kind of oxymoron, given that the term "ensemble" is typically used by fine art experts and historians of "high" architecture? Would it be correct to apply it to - as B. Rudofsky put it - non-pedigreed architecture?

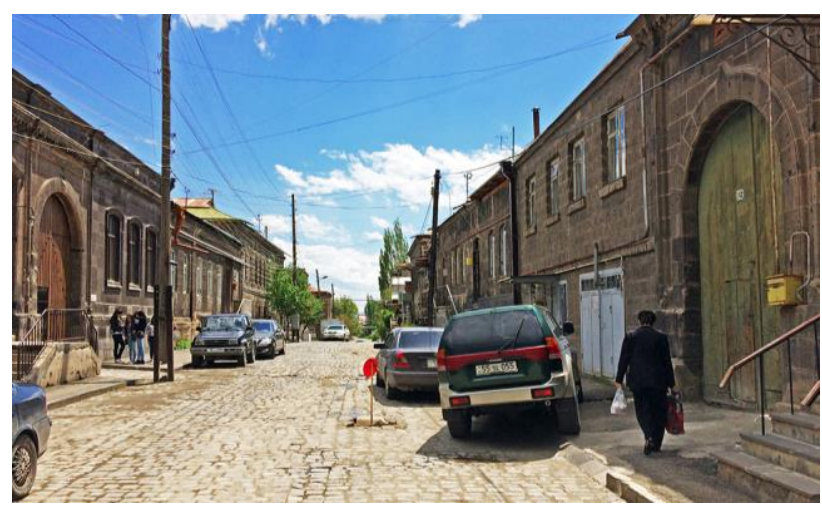

Figure 9. Vernacular ensemble of Gorganyan Street. Photo by the author, 2017. 
Without attempting to make the final judgement on the issue, I have to mention that describing Gyumri's city centre as an ensemble can be justified by it having a clear aesthetic value, as well as a number of other qualities usually attributed to an architectural ensemble: balance of proportion and scale, unique character, cultural and social recognition ${ }^{1}$.

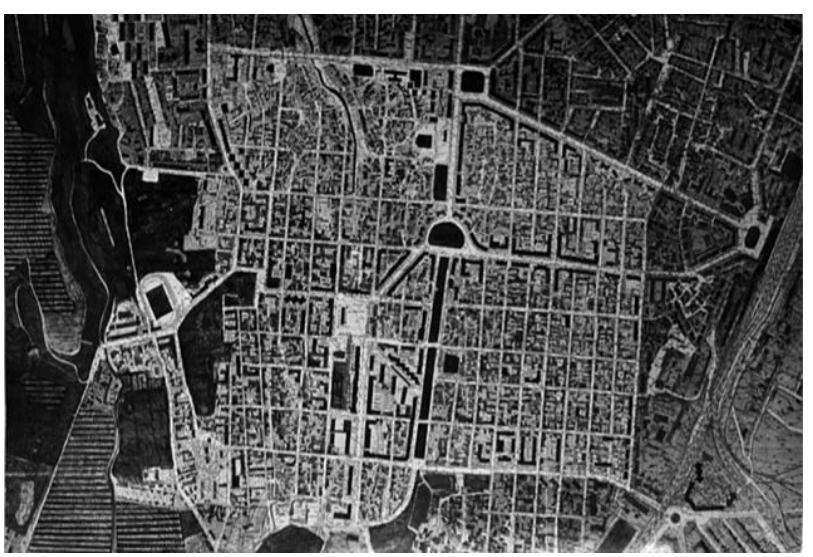

Figure 10. City plan highlighting the grounds of Kumayri Museum Preserve, 1980s. Source: personal files of Sashur Kalashyan, founder of the museum.

Yet this value is not universal, but rather of a local, domestic character. And there are obviously attributes of an ensemble, in its conventional sense, which this object does not possess (compositional harmony, stylistic coherence, hierarchical structure, uninterrupted connections between its parts). So if it is an ensemble, it is one of a kind, with certain features separating it from classical architectural ensembles.

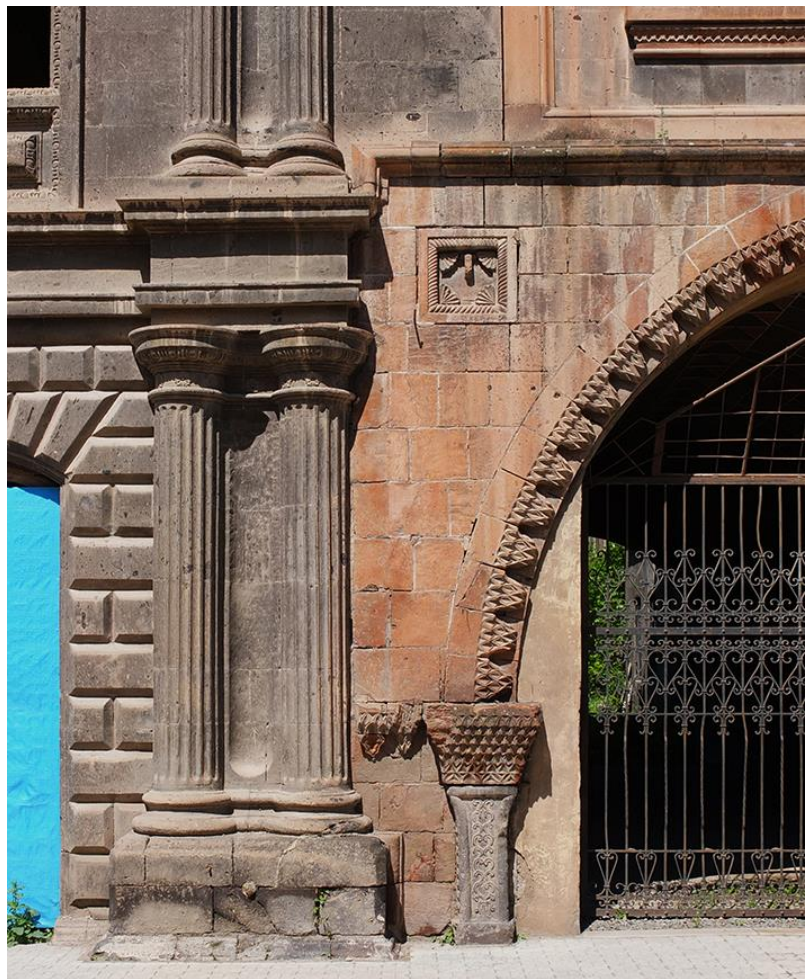

Figure 11. Fragment of Gyumri's vernacular ensemble: stylistic collage on Abovyan Street. Photo by the author, 2017.

${ }^{1}$ Otherwise, Kumayri, the largest historical and architectural museum preserve in the USSR, that includes the entire historical part of the city (ca. 1,000 hectares), would not have appeared here in 1980.
The principal distinguishing feature of VE is the subject of ensemble. It is characterised by a different type of creators ("authors" or actors of the urban environment) than the classical architectural ensemble. Of the many definitions of "ensemble", my understanding of VE is most consistent with the definition of "ensemble in stage art" in the basic encyclopedia of pre-Revolution Russia, the Brockhaus and Efron Dictionary: "A full ensemble requires artists who are aesthetically educated and conscientious in their work." (Entsiklopedicheskiy slovar'..., 1890). The vernacular Alexandropol was built by exactly that kind of artists.

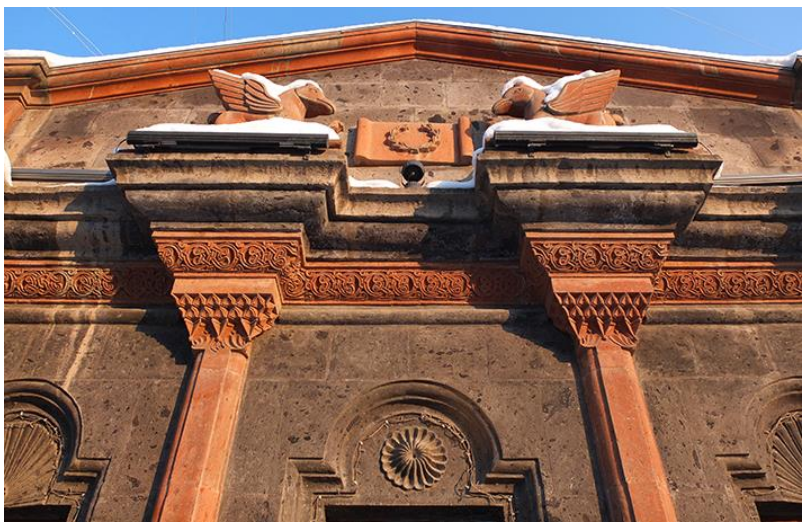

Figure 12. Fragment of Gyumri's vernacular ensemble: red tuff ornaments on the black tuff building facade on Jivani Street.

Photo by the author, 2017.

The collective subject of VE is craftsmen, "aesthetically educated" while training with senior colleagues and studying reallife and printed samples and prototypes, who act creatively within the framework of local traditions as well as planning, legal and aesthetic requirements.According to Adolf Loos, an architect is "a bricklayer who has studied Latin". It is unlikely that Gyumri masters were fluent in Latin; they spoke their own language, both figuratively (their local architectural lingua franca) and literally (the Gyumri dialect and Gyumri humour are still clearly recognised in Armenia). They were also open to improvisation, easily mixing up elements of the higher, median, and lower architectural cultures in their works.

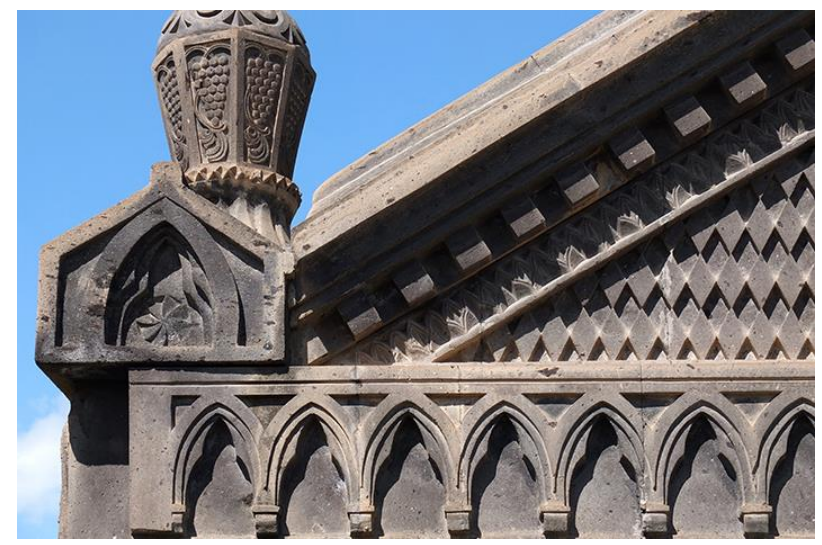

Figure 13. Fragment of the Gyumri's vernacular ensemble: a crypt in the old city cemetery. Photo by the author, 2017.

"The basic difference between classical music and jazz is that in the former the music is always graver than its performance - whereas the way jazz is performed is always more important than what is being played", - said American composer André Previn. That is how this jazz jam of a city was built; unpredictable improvisation is yet another element of its charm. 


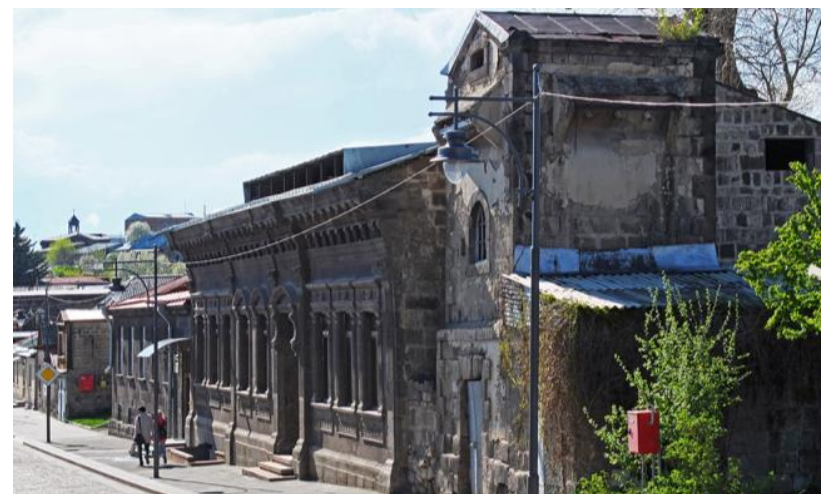

Figure 14. "House with two cornices" and electrical substation turret on Rustaveli Street. Photo by the author, 2019.

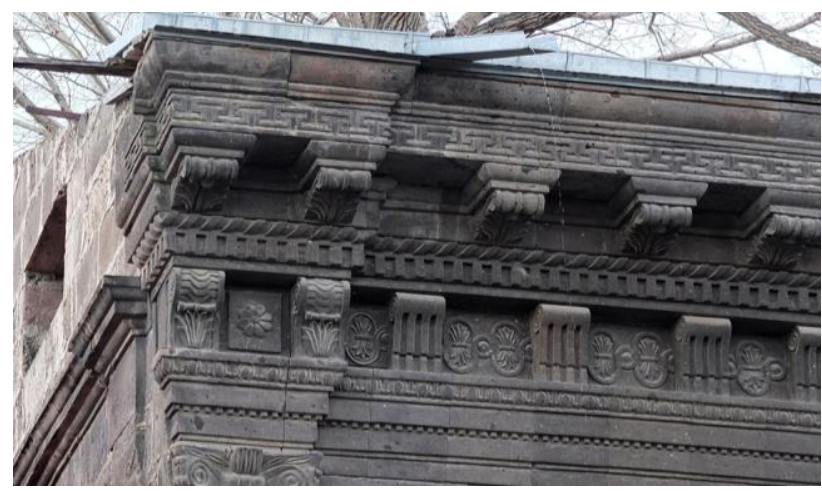

Figure 15. Interrupted axes of corbels in the lateral parts of the "House with two cornices" facade. Photo by the author, 2018.

The two neighbouring buildings on Rustaveli Street can serve as a good example. At first they might seem like a strange combination: one of Alexandropol's most palatial buildings ${ }^{2}$ and an electrical substation turret, rather unceremoniously placed next to it, most likely in the 1950s. The builders of the turret worked at a very different time than the builders of the house, in a different society, with a different kind of customer. And what we have as the result is a kind of vernacular (micro)ensemble, built on the same basic principles: handwork, love for the material, balance of proportion, respect for the context, weaving into the fabric of the place.

\subsection{Persisting vernacular of the $1950 \mathrm{~s}$}

American architectural historian Greg Castillo believes that in the "eastern" national republics, the use of local, national architectural forms in government-controlled construction had a purely external, decorative character:

Under an imperative to remake "backward" societies in the image of socialism, cultural authorities monumentalized the forms of vernacular design to symbolize the regional identity of peoples, at the same time they were eliminating the social and political structures that underpinned vernacular traditions. (Castillo, 1997).

In Leninakan, these "structures that underpinned vernacular traditions" somehow survived. We can see this in the results of the successive "grassroots" reproduction of Alexandropol's vernacular up until the late 1950 s.

${ }^{2}$ The so-called "house with two cornices", most notable for its cornices' corbel axes which are aligned in the centre, but zigzagged on the sides. The master really improvised away!

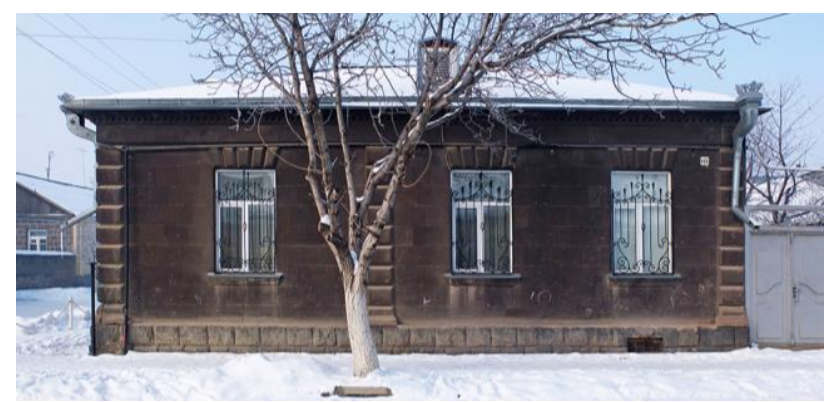

Figure 16. Gukasyan Street, 146. Photo by the author, 2018.

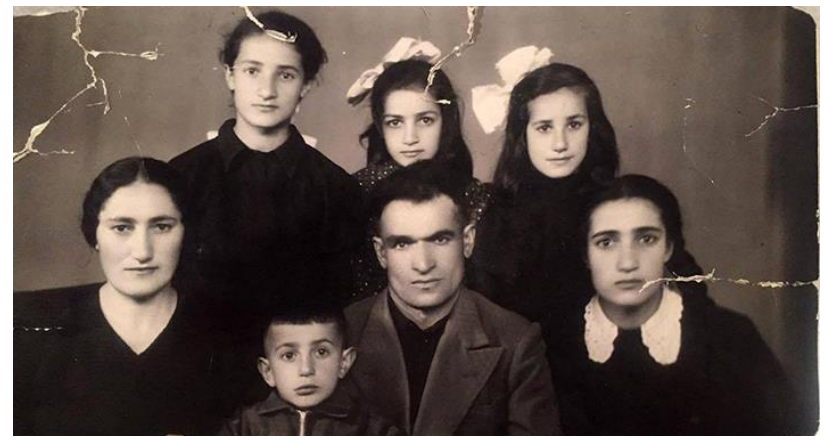

Figure 17. Master Petros and his family, 1950s. Photo from the Karapetyan family archive.

The Soviet government could not destroy the vernacular practices of residential housing. Despite the official campaign against them ${ }^{3}$, the "city of masters" managed to preserve its tradition of building private housing based on historical prototypes. The "freedom within the grid" paradigm remained in place. The city officials seemed to turn a blind eye to the everyday life happening in the regular vernacular quarters, which were partially "screened off" in the 1930s-1950s by the Stalinist-style main avenues. On the free land plots of historical quarters, creation of a normal (non-socialist, non-modernist) city continued - by the hands of its residents. For example, let's look at Number 146, Gukasyan Street, built in 1957 by master Petros Karapetyan. According to his widow, Anait Karapetyan ${ }^{4}$, the house was built on the plot provided by the city administration in the south-east of the historic part that had been planned out back in the early 20th century. It was the third house built by the master as his family expanded.

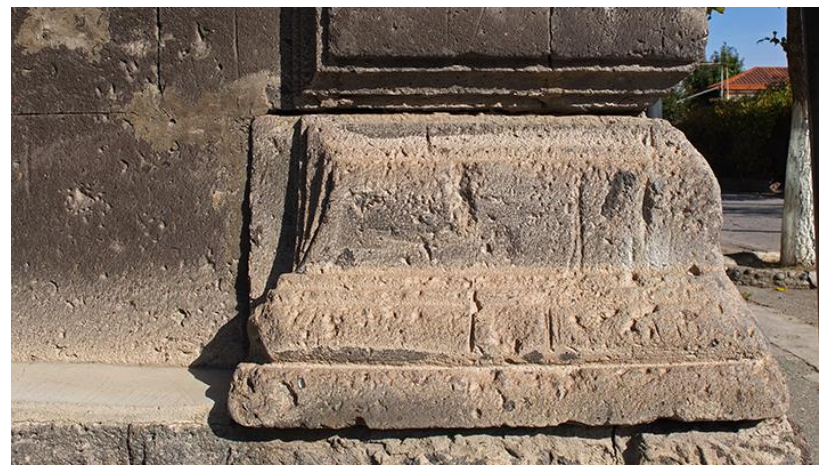

Figure 18. Gukasyan Street, 146. Detail. Photo by the author, 2018.

\footnotetext{
3 Thus, the Resolution of the Central Committee of the Armenian Communist Party On Sporadic Development and Defects in Architecture and Construction of 1931 prohibited purchasing construction projects from individuals and performing construction works without pre-approved plans. ${ }^{4}$ Interview by the author on 8 May 2017, Yerevan. Grandma Anait passed away on 12 May 2019 at the age of 97 .
} 
The master purchased the black tuff stones for the facework at the mine - five roubles per stone, ca. $1 / 150$ of the average USSR salary in 1957 - and then cut the stones with his own hands, fashioning architectural details. The other materials were not that expensive, but the whole house was built by Petros himself. His wife also worked at the construction site every day. The work ethic of this family and the fundamental equality of its members are especially interesting. Anait told me:

\section{- We built this house together, the two of us.}

- Did you help your husband?

- I didn't help him, I worked! Normally at the construction site there are the master and the workers. So Petros was the master and I was the worker. We had five children, we couldn't afford hiring anyone. We built the house early in the morning, before Petros had to leave for work. I picked the stone leftovers into buckets and used them to fill the pits in the road.

The master had to support six people (a wife, a son, and four daughters). He was actually working as a master in the construction team at the railway station at that time - not the worst, but not the highest position in Leninakan. But children had to be fitted for higher education, the girls needed a dowry, and every family rouble counted. Even so, the street facade decorations alone cost a substantial amount. It was important to build a house just as good as others, or even better, whenever possible: this was the first house in the area to be equipped with a hot water bath, which of course aroused the neighbours' curiosity and envy.

Mrs. Karapetyan described in detail the involvement of her husband's acquaintance, a city engineer, who first provided Petros with a plan for a two-storey house free of charge and then ignored the fact that due to the lack of funds a completely different, one-storey house was built. This simple-looking house to this day adorns the city, completing one of the corners of its rectangular quarters. On the thirtieth anniversary of the 1988 earthquake, the master's granddaughter, Ani Sarkisyan, recalled in her Facebook post:

My grandfather Petros was a mason... After the devastating earthquake, he asked me to take him to Gyumri, where he visited all his buildings... it was the first time that I saw tears in his eyes... 'Now, my girl, my mind is at peace. Everyone should do their job properly, then there would not have been so many victims.' The houses my grandfather had built in Gyumri survived the earthquake and are still standing...

Vernacular architecture is always sustainable. But in Gyumri's case it has also proved to be literally stable. The building's construction date is often carved on the facades here. Reading this "vernacular diary", we can see when this epoch of traditional vernacular came to an end. In was in the late 1950s and early 1960 s, when the mass construction programme was launched and people got the opportunity to solve the housing problem some other way: by receiving apartments in five-storey buildings.

\subsection{Neo-vernacular of the $21^{\text {st }}$ century}

At the beginning of the new millennium, new houses made of black tuff appeared in the city. Sometimes they are artless, sometimes - if the owners are richer - gaudy, their proportions are no longer perfect, the details are pretentious and sometimes vulgar. They were built under a cloud of disapproval from the then mayor of the city, who unofficially banned new black houses ("they are sad, and we need something bright, joyful"), but for himself built a chic black neo-vernacular mansion in the historic centre.

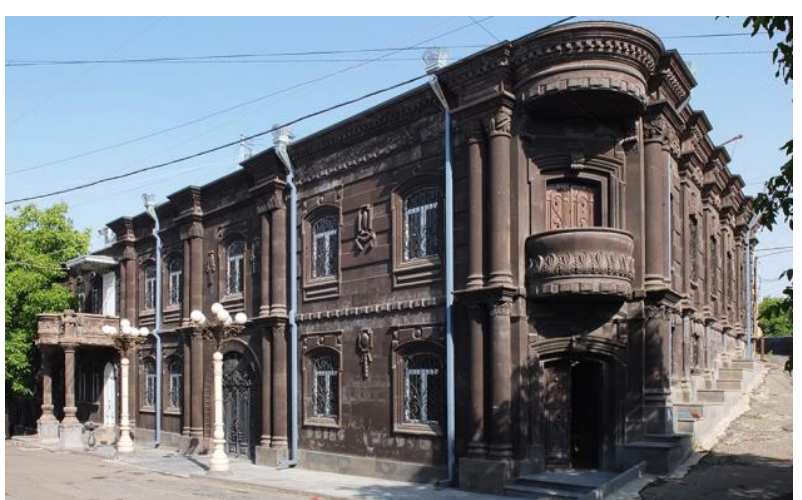

Figure 19. New black tuff houses built in the 2000s, Mayakovsky Street. Photo by the author, 2018.

There are plenty of such overly lavish, overly decorated new houses in the city centre, and the purposes they serve are far more ambitious than those of the historical vernacular. On the one hand, their customers follow the tradition (to build only on frontage lines, no higher than two floors, use traditional material and decor). On the other hand, they want not just to join the urban ensemble, but to show their own importance, to stand out in a crowd. This results in overuse of ornaments and their mutual inconsistency, violation of the unspoken rules for building facades, which the old masters followed.

But there are also more modest and appropriate one- and twostorey black houses, correctly built into the environment. They bring to the $21^{\text {st }}$ century the best traditions of the Alexandropol masters and their successors, who used to work in Leninakan just a short while ago, in the 1950s. It is well known how difficult it is to accept (and even more so to implement) restrictive construction regimes in post-Soviet historical cities. All the more surprising is the appearance of such buildings, completely appropriate and "right", emerging here without any written rules.

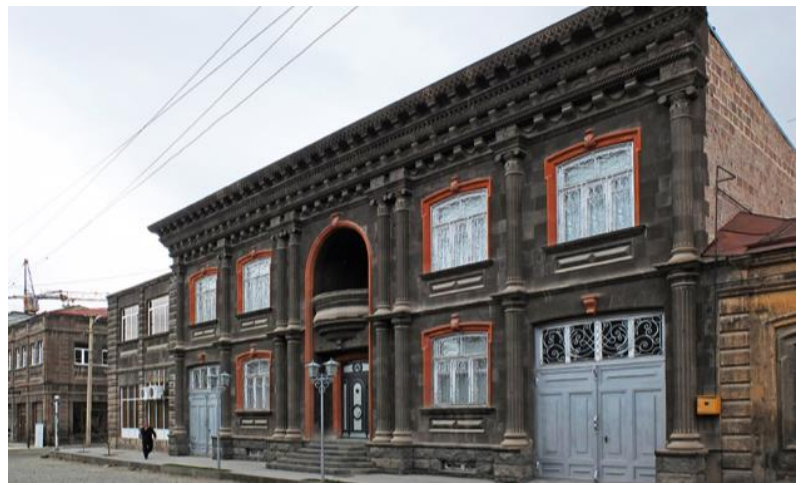

Figure 20. House on Abovyan Street, built in the 2000s - a "replica" of the "House with two cornices". Photo by the author, 2017.

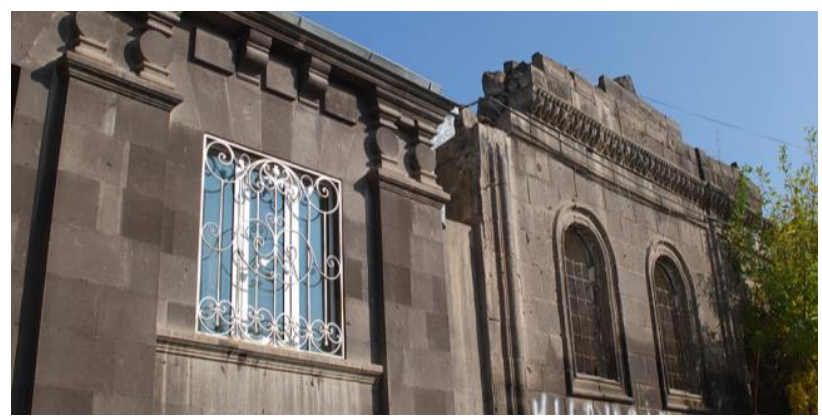

Figure 21. The new and the old black tuff houses on Shiraz Street. Photo by the author, 2018. 


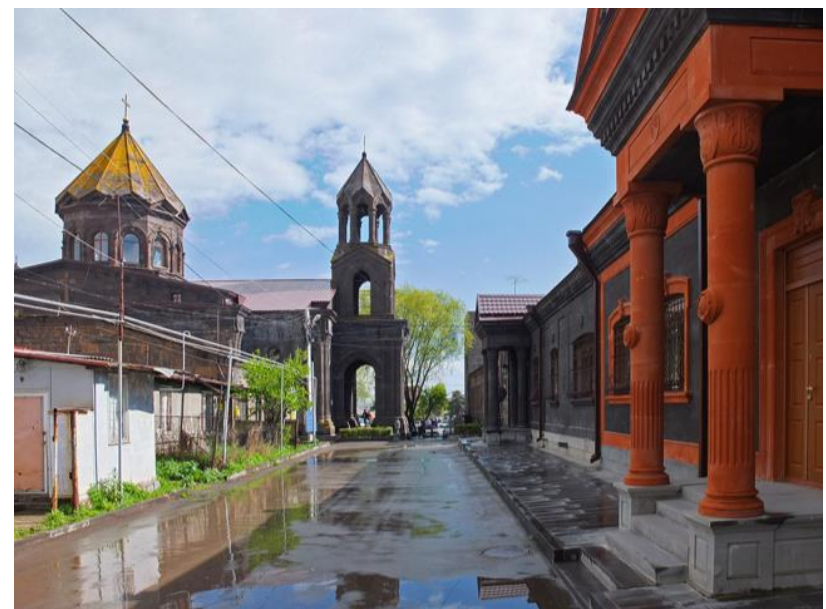

Figure 22. Single-storey houses with red tuff details, built in the 2010s, subordinate to the height of the Church of the Holy Mother of God. Photo by the author, 2019.

It is like there are some invisible, very strict regulations adopted in the city. And not that they would be impossible to break - the citizens just do not want to.

A small stone arch, very recently built on the main square, is quite symbolic: it "stitches" the cubic volume of a new black modernist building with a neighboring historical house. This only seems possible in cities like Gyumri.

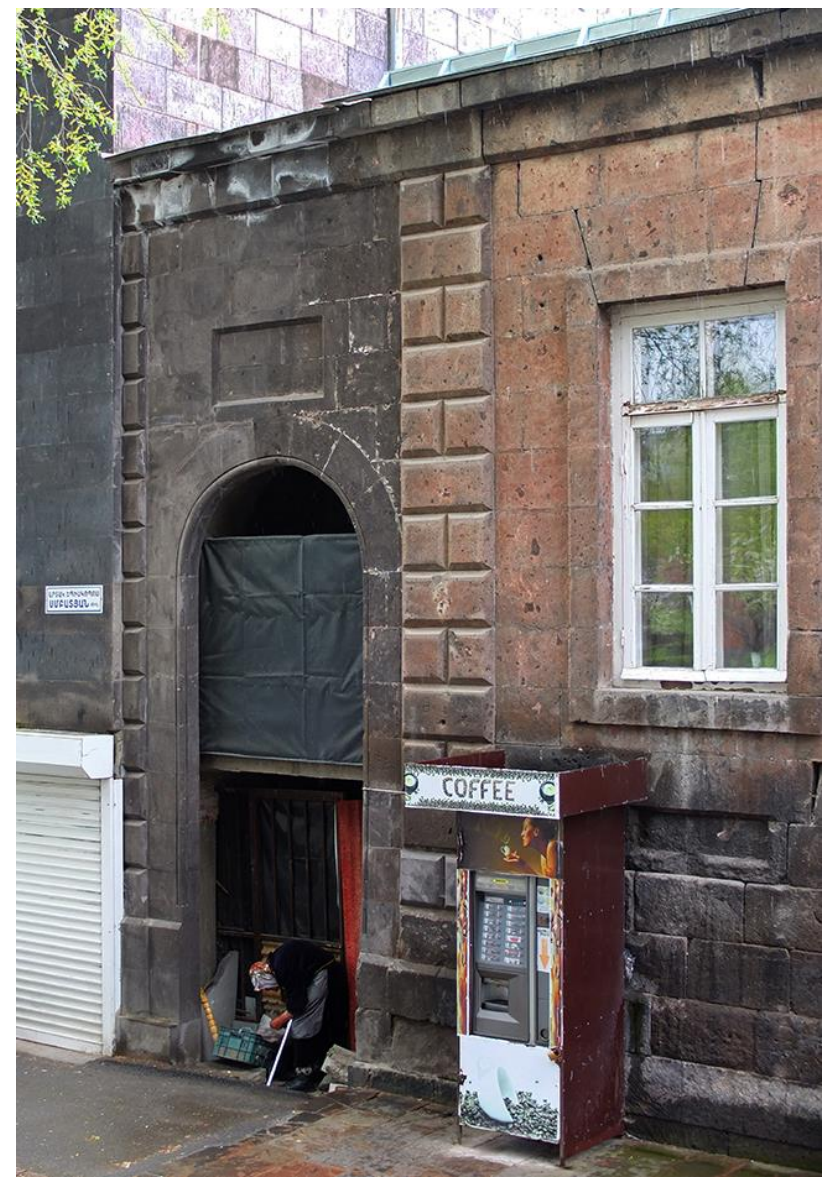

Figure 23. Archway connecting the modernist and the historical black tuff buildings. Photo by the author, 2019.

\section{CONCLUSION}

A city like this one makes me dream tall and feel in on things. Toni Morrison

The study shows that the vernacular built environment of Gyumri developed throughout its history due to the efforts of local master builders, who creatively complemented ancient and modern architectural samples in accordance with citizens' needs and tastes. The continuity of this development is evident to this day, despite the radical changes in socio-economic conditions the city has faced. In today's Armenia, Gyumri is considered the only well-preserved historical city. The authorities believe it should be developed as a tourist centre. But is this the path that best corresponds to the nature of this city, the city which was built by its residents, first and foremost, for themselves?

Today, we know how to create tourist showcases. But how do we bring the city back to its true self, how do we direct the transformations not to achieve external attractiveness, but to keep the city's own logic of self-development? This is a serious challenge for both the citizens and the professionals. To meet it, we have to carefully study the historical features and current practices of a living vernacular city. In the age of globalisation, robotisation, and total digitalisation, it is especially important to protect such rare, miraculously preserved authentic vernacular city ensembles as the historical Gyumri. Their environment, inspired by traditions, culture, and handwork, gives us hope that the modern - and future - cities can be something else, other than soulless and inhuman.

\section{REFERENCES}

Armen M., 1984: Rodnik Egnar (The Egnar's Spring). Sovetakan Groh Publ., Yerevan (in Russian).

Atlas krepostey Rossiyskoy imperii (Atlas of fortresses of the Russian Empire), s. a. Saint Petersburg.

Brausevetter, A., 1904: Arkhitekturnye formy grazhdanskikh postroek (Architectural Forms of Civil Buildings). I. I. Bazlov Publ., Saint Petersburg (in Russian).

Castillo, G., 1997. Soviet Orientalism: Socialist Realism and Built Tradition. Traditional Dwellings and Settlements Review, 8(2), 33-47.

Charter on the Built Vernacular Heritage, 1999.

Entsiklopedicheskiy slovar' Brokgauza i Yefrona (Brockhaus and Efron Encyclopedic Dictionary), 1890. Ed. I. E. Andreevskiy. Vol. Ya. Semenovskaya Tipo-Litografiya (I. A. Efron) Publ. Saint-Petersburg (in Russian).

Israelyan, R., 1982: About the architecture of Leninakan. Israelyan, $R$. Articles, researches, reviews. Institute of Art by the Academy of Science of Armenian SSR, Yerevan.

Noble, A., 2007: Traditional Buildings: A Global Survey of Structural Forms and Cultural Functions. I. B. Tauris Publ., London.

Rudofsky, B., 1964: Architecture without Architects: A Short Introduction to Non-Pedigreed Architecture. Museum of Modern Art Publ., New York.

Vysokovskiy, A., 2013: Vernacularnyi gorod (The vernacular city). 